\title{
WEIGHT-LENGTH RELATIONS FOR 103 FISH SPECIES FROM THE SOUTHERN AEGEAN SEA, TURKEY
}

\author{
Gökçen BİLGE*, Sercan YAPICI, Halit FİLIZ, and Hasan CERİM \\ Faculty of Fisheries, Muğla Sıtkı Koçman University, 48000, Kötekli, Muğla, Turkey
}

Bilge G., Yapıcı S., Filiz H., Cerim H. 2014. Weight-length relations for 103 fish species from the southern Aegean Sea, Turkey. Acta Ichthyol. Piscat. 44 (3): 263-269.

\begin{abstract}
Using a traditional, commercial, crustacean bottom trawl net we collected fish samples from the southern Aegean Sea, from Dec 2009 to Nov 2010, at depths of 30-225 m. We collected a total of 35428 specimens representing 50 families and 103 species: Argentina sphyraena Linnaeus, 1758; Arnoglossus laterna (Walbaum, 1792); Arnoglossus rueppelii (Cocco, 1844); Arnoglossus thori Kyle, 1913; Belone belone (Linnaeus, 1761); Belone svetovidovi Collette et Parin, 1970; Blennius ocellaris Linnaeus, 1758; Boops boops (Linnaeus, 1758); Bothus podas (Delaroche, 1809); Buglossidium luteum (Risso, 1810); Callionymus lyra Linnaeus, 1758; Callionymus risso Lesueur, 1814; Capros aper (Linnaeus, 1758); Cepola macrophthalma (Linnaeus, 1758); Chelidonichthys cuculus (Linnaeus, 1758); Chelidonichthys lucerne (Linnaeus, 1758); Chlorophthalmus agassizi Bonaparte, 1840; Chromis chromis (Linnaeus, 1758); Citharus linguatula (Linnaeus, 1758); Coelorinchus caelorhincus (Risso, 1810); Conger conger (Linnaeus, 1758); Coris julis (Linnaeus, 1758); Dentex dentex (Linnaeus, 1758); Diplodus annularis (Linnaeus, 1758); Diplodus sargus sargus (Linnaeus, 1758); Diplodus vulgaris (Geoffroy Saint-Hilaire, 1817); Echelus myrus (Linnaeus, 1758); Equulites klunzingeri (Steindachner, 1898); Eutrigla gurnardus (Linnaeus, 1758); Fistularia commersonii Rüppell, 1838; Gadiculus argenteus Guichenot, 1850; Glossanodon leioglossus (Valenciennes, 1848); Gobius cruentatus Gmelin, 1789; Gobius niger Linnaeus, 1758; Helicolenus dactylopterus (Delaroche, 1809); Hoplostethus mediterraneus Cuvier, 1829; Labrus merula Linnaeus, 1758; Labrus viridis Linnaeus, 1758; Lampanyctus crocodilus (Risso, 1810); Lepidorhombus boscii (Risso, 1810); Lepidorhombus whiffiagonis (Walbaum, 1792); Lepidotrigla cavillone (Lacepède, 1801); Lepidotrigla dieuzeidei Blanc et Hureau, 1973; Lesueurigobius friesii (Malm, 1874); Lithognathus mormyrus (Linnaeus, 1758); Liza ramada (Risso, 1827); Lophius budegassa Spinola, 1807; Lophius piscatorius Linnaeus, 1758; Macroramphosus scolopax (Linnaeus, 1758); Merluccius merluccius (Linnaeus, 1758); Mullus barbatus barbatus Linnaeus, 1758; Mullus surmuletus Linnaeus, 1758; Mustelus mustelus (Linnaeus, 1758); Mustelus punctulatus Risso, 1827; Nemipterus randalli Russell, 1986; Oblada melanura (Linnaeus, 1758); Pagellus acarne (Risso, 1827); Pagellus bogaraveo (Brünnich, 1768); Pagellus erythrinus (Linnaeus, 1758); Parablennius tentacularis (Brünnich, 1768); Peristedion cataphractum (Linnaeus, 1758); Pomadasys incisus (Bowdich, 1825); Pomatoschistus minutus (Pallas, 1770); Raja miraletus Linnaeus, 1758; Raja radula Delaroche, 1809; Salaria pavo (Risso, 1810); Saurida undosquamis (Richardson, 1848); Sciaena umbra Linnaeus, 1758; Scomber japonicas Houttuyn, 1782; Scophthalmus rhombus (Linnaeus, 1758); Scorpaena notata Rafinesque, 1810; Scorpaena porcus Linnaeus, 1758; Scorpaena scrofa Linnaeus, 1758; Scyliorhinus canicula (Linnaeus, 1758); Scyliorhinus stellaris (Linnaeus, 1758); Serranus cabrilla (Linnaeus, 1758); Serranus hepatus (Linnaeus, 1758); Serranus scriba (Linnaeus, 1758); Solea solea (Linnaeus, 1758); Sphyraena chrysotaenia Klunzinger, 1884; Spicara maena (Linnaeus, 1758); Spondyliosoma cantharus (Linnaeus, 1758); Squalus blainvillei (Risso, 1827); Symphodus cinereus (Bonnaterre, 1788); Symphodus doderleini Jordan, 1890; Symphodus mediterraneus (Linnaeus, 1758); Symphodus melanocercus (Risso, 1810); Symphodus ocellatus (Linnaeus, 1758); Symphodus rostratus (Bloch, 1791); Symphodus tinca (Linnaeus, 1758); Syngnathus acus Linnaeus, 1758; Torpedo marmorata Risso, 1810; Torpedo nobiliana Bonaparte, 1835; Trachinus draco Linnaeus, 1758; Trachurus mediterraneus (Steindachner, 1868); Trachurus picturatus (Bowdich, 1825); Trachurus trachurus (Linnaeus, 1758); Trigla lyra Linnaeus, 1758; Trigloporus lastoviza (Bonnaterre, 1788); Upeneus moluccensis (Bleeker, 1855); Upeneus pori Ben-Tuvia et Golani, 1989; Uranoscopus scaber Linnaeus, 1758; Zeus faber Linnaeus, 1758. We estimated weight-length relations for the fishes collected. Values of the allometric coefficient (b) ranged from 2.1729 for Cepola macrophthalma to 3.6372 for Equulites klunzingeri.
\end{abstract}

\footnotetext{
* Correspondence: Dr. Gökçen BİLGE, Muğla Sitkı Koçman Universitesi, Su Ürünleri Fakültesi, 48000, Kötekli, Muğla, Turkey, phone: (+90) 2522113168, e-mail: (GB)gbilge@mu.edu.tr, (SY)sercanyapici@mu.edu.tr, (HF)sharkturk@yahoo.com, (HC) hasancerim@mu.edu.tr.
} 
All relations were highly significant $(P<0.001)$, with the majority $(94.17 \%$ of 103 species $) r^{2}$ values being greater than 0.9 . Four species evidenced isometric growth, 50 species showed positive allometry, and 49 species have negative allometry. Seven species studied were Lessepsian migrants.

Keywords: WLR, marine fishes, Mediterranean Sea

Fisheries management and research often require the use of biometric relations in order to transform data collected in the field into appropriate indexes (Anderson and Gutreuter 1983, Écoutin and Albaret 2003, Mendes et al. 2004). In the fisheries science, weight-length relations (WLRs) have a several uses. They allow to:

- estimate weight from length for individual fish and for length classes of fish;

- estimate standing-crop biomass when the length frequency distribution is known (Anderson and Gutreuter 1983, Petrakis and Stergiou 1995);

- convert growth-in-length equations to growth-inweight for prediction of weight-at-age and use in stock assessment models (Pauly 1993);

- calculate condition indices (Anderson and Gutreuter 1983, Petrakis and Stergiou 1995); and

- compare populations from different regions in terms of their life histories and morphology (Petrakis and Stergiou 1995).

Previous studies were carried out on the characterization of WLRs for fish species (numbers of the species within the parenthesis) in the Turkish coasts of the Aegean Sea: Akyol et al. (2007) (25), Ceyhan et al. (2009) (17), Filiz and Bilge (2004) (24), Gurkan et al. (2010) (22), İlkyaz et al. (2008) (62), Ismen et al. (2007) (63), Karakulak et al. (2006) (47), Özaydın et al. (2007) (60) and Özaydin and Taskavak (2006) (47). In the presently reported study, WLRs were estimated for 103 fish species captured off the Turkish coasts of the southern Aegean Sea.

From December 2009 to November 2010 we sampled southern Aegean Sea fishes from a total of 68 hauls taken by a crustacean trawl vessel F/V AKYARLAR from the depths of 30-225 m. The vessel used a traditional bottom trawl net (44 mm stretched mesh size), locally called "Ottoman net". The towing time was $30 \mathrm{~min}$, at the speed of approximately 2.5 knots. The collected fish specimens were identified on board and then stored on ice until returned to the laboratory. In the laboratory, each fish was measured for total length (TL) to the nearest $0.1 \mathrm{~cm}$ and weighed (wet weight, $W$ ) to the nearest $0.01 \mathrm{~g}$. Fish species were identified based on Whitehead et al. (1986) and validated following FishBase (Froese and Pauly 2013). The relation between weight and length,

$$
W=a L^{b}
$$

was converted into the logarithmic expression:

$$
\ln W=\ln a+b \ln L
$$

Parameters $a$ and $b$ were calculated by least-squares regression, as was the coefficient of determination $\left(r^{2}\right)$. Significant difference of $b$ values from 3, which represent isometric growth, was tested with the $t$-test (Pauly 1993).

We sampled a total of 35428 fish specimens representing 50 families and 103 species (Table 1): Argentina sphyraena Linnaeus, 1758; Arnoglossus laterna (Walbaum, 1792); Arnoglossus rueppelii (Cocco, 1844); Arnoglossus thori Kyle, 1913; Belone belone (Linnaeus, 1761); Belone svetovidovi Collette et Parin, 1970; Blennius ocellaris Linnaeus, 1758; Boops boops (Linnaeus, 1758); Bothus podas (Delaroche, 1809); Buglossidium luteum (Risso, 1810); Callionymus lyra Linnaeus, 1758; Callionymus risso Lesueur, 1814; Capros aper (Linnaeus, 1758); Cepola macrophthalma (Linnaeus, 1758); Chelidonichthys cuculus (Linnaeus, 1758); Chelidonichthys lucerne (Linnaeus, 1758); Chlorophthalmus agassizi Bonaparte, 1840; Chromis chromis (Linnaeus, 1758); Citharus linguatula (Linnaeus, 1758); Coelorinchus caelorhincus (Risso, 1810); Conger conger (Linnaeus, 1758); Coris julis (Linnaeus, 1758); Dentex dentex (Linnaeus, 1758); Diplodus annularis (Linnaeus, 1758); Diplodus sargus sargus (Linnaeus, 1758); Diplodus vulgaris (Geoffroy Saint-Hilaire, 1817); Echelus myrus (Linnaeus, 1758); Equulites klunzingeri (Steindachner, 1898); Eutrigla gurnardus (Linnaeus, 1758); Fistularia commersonii Rüppell, 1838; Gadiculus argenteus Guichenot, 1850; Glossanodon leioglossus (Valenciennes, 1848); Gobius cruentatus Gmelin, 1789; Gobius niger Linnaeus, 1758; Helicolenus dactylopterus (Delaroche, 1809); Hoplostethus mediterraneus Cuvier, 1829; Labrus merula Linnaeus, 1758; Labrus viridis Linnaeus, 1758; Lampanyctus crocodilus (Risso, 1810); Lepidorhombus boscii (Risso, 1810); Lepidorhombus whiffiagonis (Walbaum, 1792); Lepidotrigla cavillone (Lacepède, 1801); Lepidotrigla dieuzeidei Blanc et Hureau, 1973; Lesueurigobius friesii (Malm, 1874); Lithognathus mormyrus (Linnaeus, 1758); Liza ramada (Risso, 1827); Lophius budegassa Spinola, 1807; Lophius piscatorius Linnaeus, 1758; Macroramphosus scolopax (Linnaeus, 1758); Merluccius merluccius (Linnaeus, 1758); Mullus barbatus barbatus Linnaeus, 1758; Mullus surmuletus Linnaeus, 1758; Mustelus mustelus (Linnaeus, 1758); Mustelus punctulatus Risso, 1827; Nemipterus randalli Russell, 1986; Oblada melanura (Linnaeus, 1758); Pagellus acarne (Risso, 1827); Pagellus bogaraveo (Brünnich, 1768); Pagellus erythrinus (Linnaeus, 1758); Parablennius tentacularis (Brünnich, 1768); Peristedion cataphractum (Linnaeus, 1758); Pomadasys incisus (Bowdich, 1825); Pomatoschistus minutus (Pallas, 1770); Raja miraletus Linnaeus, 1758; Raja radula Delaroche, 1809; Salaria pavo (Risso, 1810); Saurida undosquamis (Richardson, 1848); Sciaena umbra Linnaeus, 1758; Scomber japonicas Houttuyn, 1782; Scophthalmus rhombus (Linnaeus, 1758); Scorpaena notata Rafinesque, 1810; Scorpaena porcus Linnaeus, 1758; Scorpaena scrofa Linnaeus, 1758; Scyliorhinus canicula (Linnaeus, 1758); Scyliorhinus stellaris (Linnaeus, 1758); Serranus 
$\underset{\frac{0}{0}}{\frac{0}{\sigma}}$

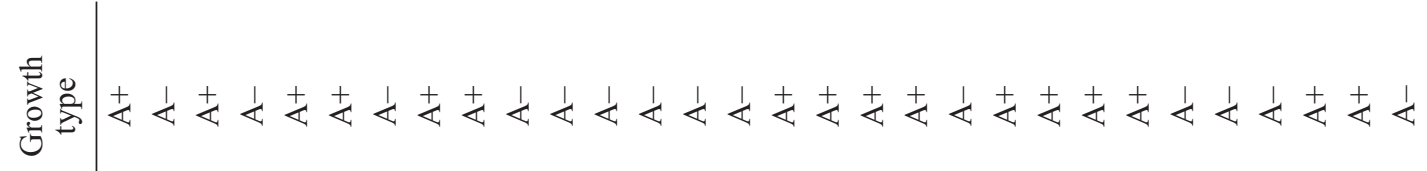

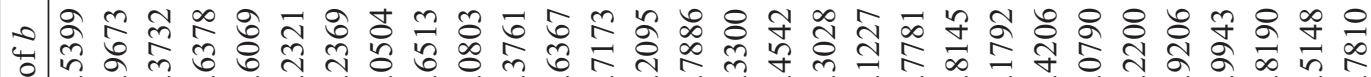
- त

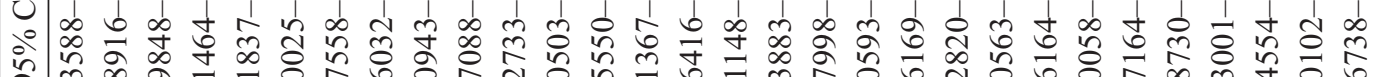

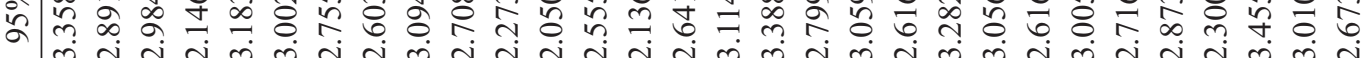

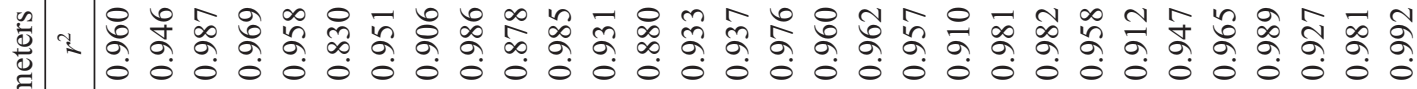

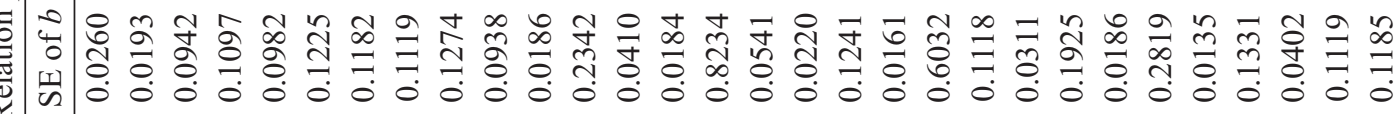
-

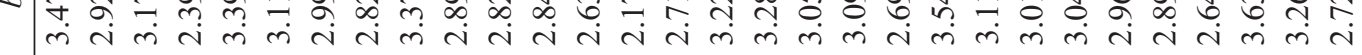

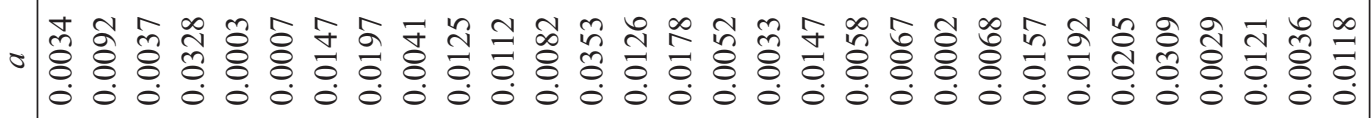

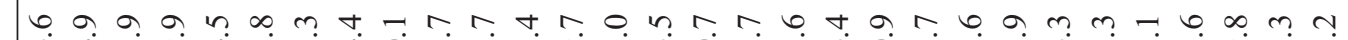
ง

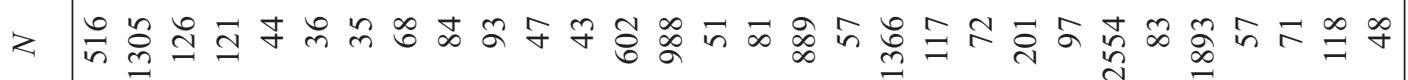

星 $\circ$

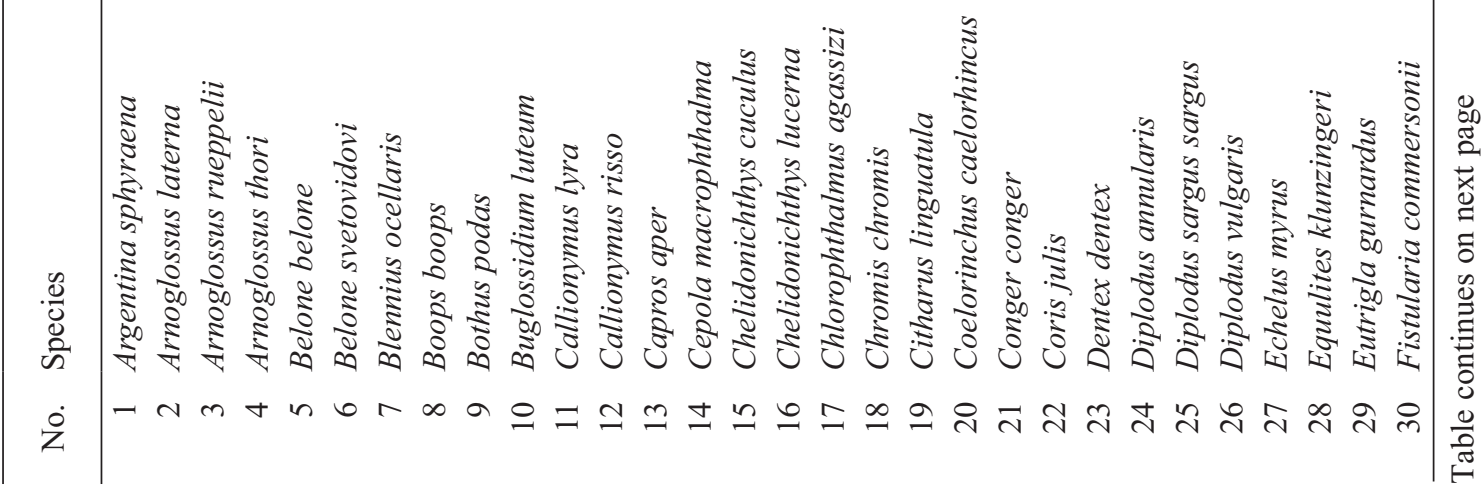




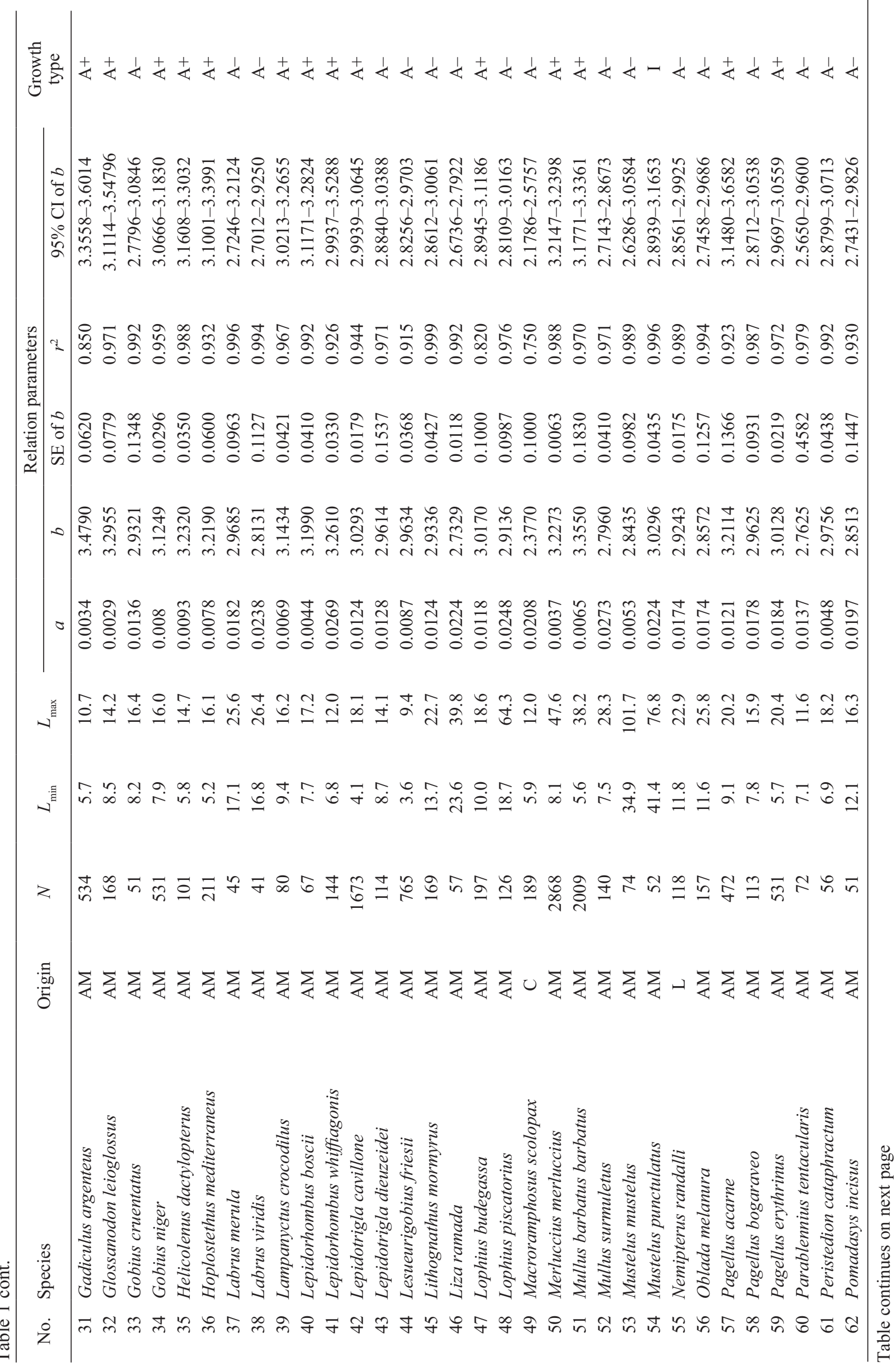




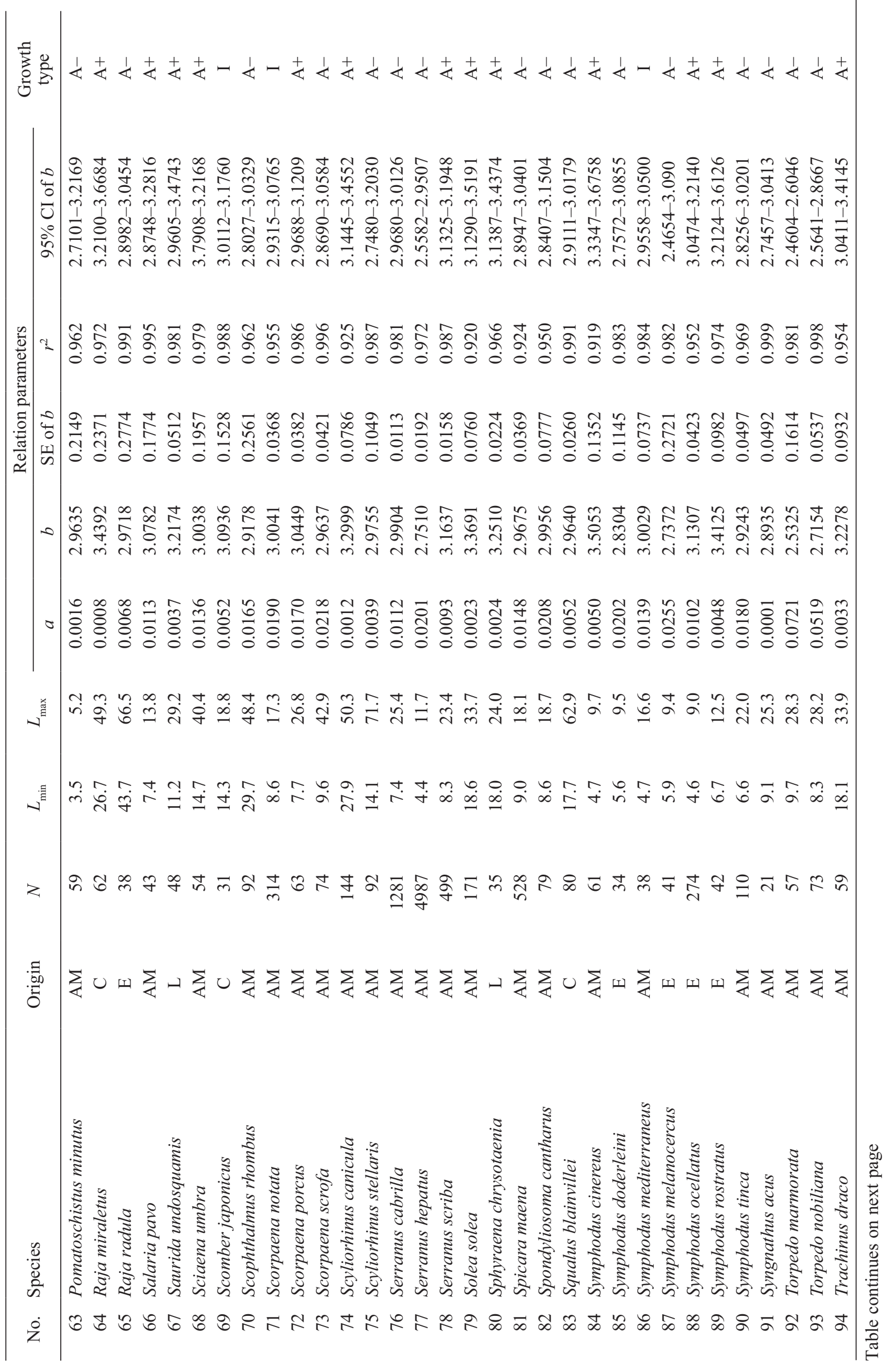




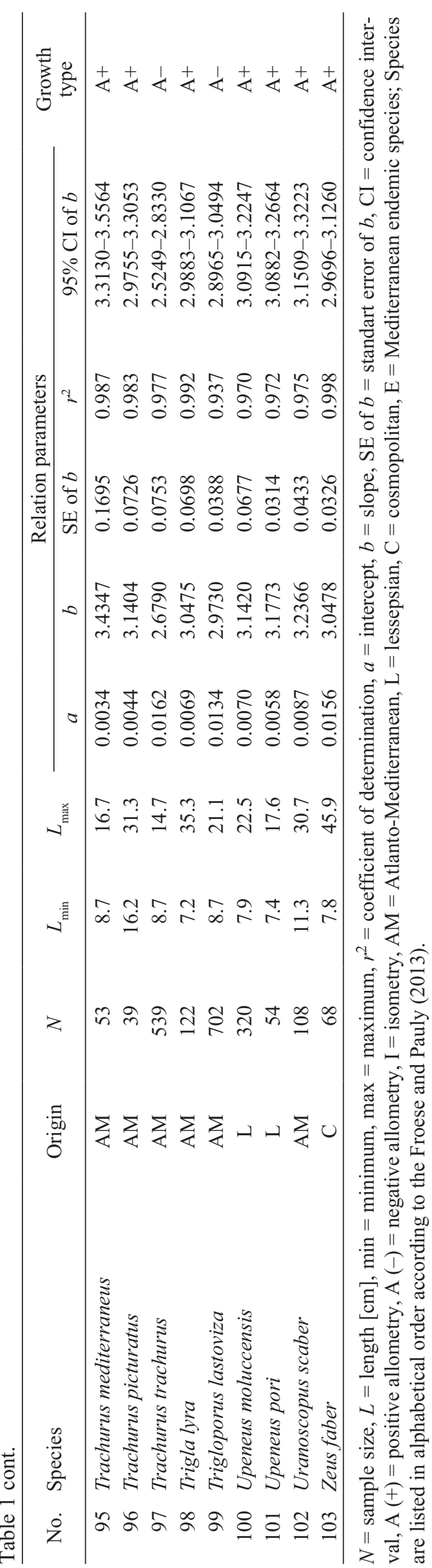

cabrilla (Linnaeus, 1758); Serranus hepatus (Linnaeus, 1758); Serranus scriba (Linnaeus, 1758); Solea solea (Linnaeus, 1758); Sphyraena chrysotaenia Klunzinger, 1884; Spicara maena (Linnaeus, 1758); Spondyliosoma cantharus (Linnaeus, 1758); Squalus blainvillei (Risso, 1827); Symphodus cinereus (Bonnaterre, 1788); Symphodus doderleini Jordan, 1890; Symphodus mediterraneus (Linnaeus, 1758); Symphodus melanocercus (Risso, 1810); Symphodus ocellatus (Linnaeus, 1758); Symphodus rostratus (Bloch, 1791); Symphodus tinca (Linnaeus, 1758); Syngnathus acus Linnaeus, 1758; Torpedo marmorata Risso, 1810; Torpedo nobiliana Bonaparte, 1835; Trachinus draco Linnaeus, 1758; Trachurus mediterraneus (Steindachner, 1868); Trachurus picturatus (Bowdich, 1825); Trachurus trachurus (Linnaeus, 1758); Trigla lyra Linnaeus, 1758; Trigloporus lastoviza (Bonnaterre, 1788); Upeneus moluccensis (Bleeker, 1855); Upeneus pori BenTuvia et Golani, 1989; Uranoscopus scaber Linnaeus, 1758; Zeus faber Linnaeus, 1758.

Out of the 103 fish species sampled, 84 (81.55\%) were of the Atlanto-Mediterranean origin, 7 (6.80\%) were endemic to the Mediterranean, 5 (4.85\%) were cosmopolitan, and $7(6.80 \%)$ were Lessepsian migrants (Table 1). Sparidae (10.7\%; 11 species), Labridae (9.7\%; 10 species), and Triglidae $(6.8 \% ; 7$ species $)$ were the most abundant families. Sample sizes ranged from 21 for Syngnathus acus, to 4987 for Serranus hepatus (Table 1). The sample size, minimum and maximum length for each species are presented in Table 1, as well as the WLRs, the coefficient of determination $\left(r^{2}\right)$ and the standard error and confidence interval (CI) of $b$. Values of the allometric coefficient $(b)$ ranged from 2.1729 for Cepola macrophthalma to 3.6372 for Equulites klunzingeri (Table 1). The mean value of $b$ ( \pm standard deviation) was $3.029( \pm 0.2756)$ and the median $b$ was 3.0031 , with $50 \%$ of the $b$ values being between 2.924 and 3.183. Overall, the values of the parameter $b$ vary between 2 and 4 (Tesch 1971). In the presently reported study $94.2 \%$ of the 103 species had $b$ values within the expected range of 2.5-3.5 (Koutrakis and Tsikliras 2003) with 2.5325 for Torpedo marmorata and 3.4790 for Gadiculus argenteus. All relations were highly significant $(P<0.001)$, with the majority of (94.17\% of 103 species) $r^{2}$ values being greater than 0.9 (Table 1). There were only six exceptions: Macroramphosus scolopax, Lophius budegassa, Belone svetovidovi, Gadiculus argenteus, Buglossidium luteum, and Capros aper (Table 1). Concerning the type of growth, 4 species $(3.9 \%$ of the total species number) showed isometric growth $(b=3), 50$ species $(48.5 \%)$ positive allometry $(b>3)$, and 49 species $(47.6 \%)$ negative allometry $(b<3)$.

Fish samples in this study were intermittently collected throughout the year. Estimated WLR parameters should be considered only as mean annual values for most of these species since the data were collected over an extensive period of time and are not representative of any particular season (Dulčić and Glamuzina 2006). As stressed by Bagenal and Tesch (1978) and Petrakis and Stergiou (1995), the use of these relations should be limited to the size range used to estimate the parameters. 


\section{ACKNOWLEDGEMENTS}

This research was supported by the Muğla Sitki Koçman University Scientific Research Fund (BAP 09/31). We would like to thank the "Republic of Turkey, Ministry of Agriculture and Rural Affairs, General Directorate of Protection and Control" and "Turkish Coast Guard Command (TCGC)" and "TCG Aegean Sea Area Command" for giving trawl permission in prohibited areas during the survey.

\section{REFERENCES}

Akyol O., Kinacigil H.T., Şevik R. 2007. Longline fishery and length-weight relationships for selected fish species in Gökova Bay (Aegean Sea, Turkey). International Journal of Natural and Engineering Sciences 1: 1-4.

Anderson R.O., Gutreuter S.J. 1983. Length, weight, and associated structural indices. Pp. 283-300. In: Nielsen L., Johnson D. (eds.) Fisheries techniques. American Fisheries Society, Bethesda, MD, USA.

Bagenal T.B., Tesch F.W. 1978. Age and growth. Pp. 101-136. In: Bagenal T. (ed) Methods for assessment of fish production in fresh waters. 3rd edn. IBP Handbook No. 3. Blackwell Scientific Publications, Oxford, UK.

Ceyhan T., Akyol O., Erdem M. 2009. Length-weight relationships of fishes from Gökova Bay, Turkey (Aegean Sea). Turkish Journal of Zoology 33 (1): 69-72. DOI: 10.3906/zoo-0802-9

Dulčić J., Glamuzina B. 2006. Length-weight relationships for selected fish species from three eastern Adriatic estuarine systems (Croatia). Journal of Applied Ichthyology 22 (4): 254-256. DOI: 10.1111/j.1439-0426.2006.00633.x

Écoutin J.M., Albaret J.J. 2003. Length-weight relationship of 52 fish species from West African estuaries and lagoons. Cybium 27 (1): 3-9.

Filiz H., Bilge G. 2004. Length-weight relationships of 24 fish species from the North Aegean Sea, Turkey. Journal of Applied Ichthyology 20 (5): 431-432. DOI: 10.1111/j.14390426.2004.00582.x

Froese R., Pauly D. (eds.) 2013. FishBase. [version 12/2013] http://www.fishbase.org

Gurkan S., Bayhan B., Akcinar S.C., Taskavak E. 2010. Length-weight relationship of fish from shallow waters of Candarli Bay (North Aegean Sea, Turkey). Pakistan Journal of Zoology 42 (4): 495-498.
İlkyaz A.T., Metin G., Soykan O., Kinacigil H.T. 2008. Length-weight relationship of 62 fish species from the central Aegean Sea, Turkey. Journal of Applied Ichthyology 24 (6): 699-702. DOI: 10.1111/j.1439-0426.2008.01167.x

Ismen A., Ozen O., Altinagac U., Ozekinci U., Ayaz A. 2007. Weight-length relationships of 63 fish species in Saros Bay, Turkey. Journal of Applied Ichthyology 23 (6): 707-708. DOI: 10.1111/j.1439-0426.2007.00872.x

Karakulak F.S., Erk H., Bilgin B. 2006. Length-weight relationships for 47 coastal fish species from the northern Aegean Sea, Turkey. Journal of Applied Ichthyology 22 (4): 274-278. DOI: $10.1111 /$ j.1439-0426.2006.00736.x

Koutrakis E.T., Tsikliras A.C. 2003. Length-weight relationships of fishes from three northern Aegean estuarine systems (Greece). Journal of Applied Ichthyology 19 (4): 258-260. DOI: 10.1046/j.1439-0426.2003.00456.x

Mendes B., Fonseca P., Campos A. 2004. Weight-length relationships for 46 fish species of the Portuguese west coast. Journal of Applied Ichthyology 20 (5): 355-361. DOI: 10.1111/j.1439-0426.2004.00559.x

Özaydin O., Taskavak E. 2006. Length-weight relationships for 47 fish species from Izmir Bay (eastern Aegean Sea, Turkey). Acta Adriatica 47 (2): 211-216.

Özaydın O., Uçkun D., Akalın S., Leblebici S., Tosunoğlu Z. 2007. Length-weight relationships of fishes captured from Izmir Bay, central Aegean Sea. Journal of Applied Ichthyology 23 (6): 695-696. DOI: 10.1111/j.14390426.2007.00853.x

Pauly D. 1993. Fishbyte section editorial. Naga, the ICLARM Quarterly 16 (2-3): 26.

Petrakis G., Stergiou K.I. 1995. Weight-length relationships for 33 fish species in Greek waters. Fisheries Research 21 (3-4): 465-469. DOI: 10.1016/0165-7836(94)00294-7

Tesch F.W. 1971. Age and growth. Pp. 97-130. In: Ricker W.E. (ed). Methods for assessment of fish production in fresh waters. 2nd edn. International Biological Programme and Blackwell Scientific Publications, Oxford and Edinburgh, UK.

Whitehead P.J.P., Bauchot M.-L., Hureau J.-C., Nielsen J., Tortonese E. (eds.) 1986. Fishes of the north-eastern Atlantic and the Mediterranean. UNESCO, Paris.

Received: 20 March 2014

Accepted: 10 September 2014

Published electronically: 15 October 2014 